\title{
Kafkasya'da Osmanlı Tahkîmatı: Sohum Kalesi (1723-1729)
}

Cengiz Fedakar*

\section{Özet}

II. Mehmet, Sohum merkezli Abhazya'yı 1454 yılında fethetmişti. Osmanlı hâkimiyetine geçtikten sonra Doğu Karadeniz ticaretinin, Sohum İskelesi ve bölgenin güvenliği için burada eski Ceneviz kalıntıları üzerine yeniden dört tabyalı ve üç kapılı taştan bir kale inşa edilmiştir. Inşaat faaliyetleri 1723 yılından 1729 yılına kadar sürmüştür. İnşaat için lazım olan kereste ve taş bölgeden karşılanırken, işçiler daha çok Anadolu ve İstanbul'dan temin edilmiştir. Kalenin iaşe, mühimmat, cephane ve asker ihtiyacı ise İstanbul, Anadolu, Rumeli ve Kırım'dan temin edilmiştir. 18. Yüzyılın ikinci yarısında artan Rus tehdidi buranın önemini arttırınca bölgedeki diğer kalelerle birlikte Sohum Kalesi de güçlendirilmiştir. Çeşitli dönemlerde Osmanlı-Rus savaşlarında işgale uğramış, nihayetinde ise fiili olarak 1812 Bükreş Antlaşmasından sonra, resmi olarak 1829 Edirne Antlaşmasından sonra tüm Kafkasya ile birlikte Rusya sınırlarında kalmıştır.

Anahtar Kelimeler: Sohum Kalesi, Abhaz, Kafkasya, Osmanlı, Rusya.

\section{Ottoman Fortification in Caucasus: The Sokhumi Castle (1723- 1729)}

\section{Abstract}

Mehmet II conquered the region of Abkhazia with its center at Sochumi in 1454. For providing the security of the Eastern Black Sea trade, the Sochumi pier and the region, a four-tabed and three-door stone fortress was built over the ruins of an ancient Genoese fortress. The construction activities continued from 1723 until 1729. Workers were mostly supplied from Anatolia and Istanbul while the timber and

\footnotetext{
* Doç. Dr., Trakya Üniversitesi, Edebiyat Fakültesi, Tarih Bölümü, fedakarca@gmail.com. (ORCID ID: 0000-0003-1253-3771).

(Makale Gönderim Tarihi: 19.06.2017, Makale Kabul Tarihi: 14.08.2017).
}

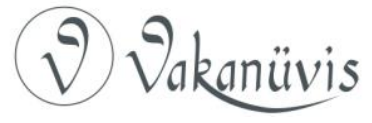


stone needed for construction were brought from the vicinity of the fortress. The forts' deposits, ammunition and military needs were met from Istanbul, Anatolia, Rumelia and Crimea. In the second half of the 18th century, due to the increasing Russian threat, the Sochumi fortress was further fortified along with the other fortress of the region. The Sochumi was invaded during Ottoman-Russian wars during the course of 18 th and 19 th century.Following the treaty of Bucharest, it remained in the Russian control unofficially, and, after the 1829 Treaty of Edirne, passed to the Russians oficially.

Keywords: Sokhumi Fortress, Abkhazian, Caucasus, Ottoman, Russia.

Kafkasya denilen bölge, ana hatlarıyla güneyde Çoruh, Arpaçay ve Aras nehirleri; batıda Karadeniz; doğuda Hazar Denizi ve Kuzeyde ise Hazar Denizi'ne dökülen Kuma ve Azak Denizi'ne dökülen Kuban Nehri ile sınırlandırılır. Yüzölçümü 440.194 km karedir. Oldukça dağlık bir coğrafyaya sahip olan Kafkasya'yı, kuzeybatı-güneydoğu yönünden uzunluğu 1500 km olan Kafkas Dağları Kafkasya'yı güney ve kuzey olmak üzere ikiye ayırır. Bu hat, Avrupa ve Asya kıtalarının sınırını da teşkil eder ${ }^{1}$.

Kuzey Kafkasya'da Rusya Federasyonu'na bağıı Dağısan, Kalmukya, Karaçay-Çerkes, Kabardey-Balkar, Inguşetya, Kuzey Osetya ve Çeçenistan cumhuriyetleri yer alır. Güney Kafkasya'da ise Azerbaycan, Ermenistan, Gürcistan ve Abhazya devletleri bulunmaktadır. Küçük ülkeler olmasına rağmen bünyelerinde çeşitli özerk bölgeleri de barındıran bu devletlerden, araştırmamıza konu olan "Sohum Kalesi" günümüzde 'de facto' Abhazya Cumhuriyeti'nin başkenti Sohum şehridir. Abhazya'nın tarihi çok eskilere dayanır. Bölgenin yerli halkı olan Abhazlar, Adige ve Ubıhlarla akraba bir halktır.

Tarih boyunca çeşitli istilalara maruz kalan bu bölge, M.Ö VII. asırda İskit Türklerinin, MÖ. II. Asırda Bulgar Türklerinin; MS. VII. Asırda Hazar

\footnotetext{
${ }^{1}$ Sadık Müfit Bilge, Osmanlı Çă̆ı'nda Kafkasya, 1454-1829 (Tarih-Toplum-Ekonomi), İstanbul 2015, 1-2.
}

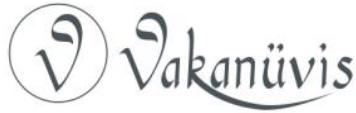


Türklerinin Kafkasya'ya hâkim olduğu görülür. İslâm halifeleri $\mathrm{Hz}$ Osman (644-656) ve Hz. Ali (656-661) zamanlarında Kafkasya'ya akınlar yapılmış, Azerbaycan fethedilmiş, Gürcistan ise vergiye bağlanmıştır².

XVIII Yüzyıl tarihçisi Vakhuşti Bagration'a göre bu günkü Abhazya toprakları "Abhaz ve Kartvel krallığı" içerisinde üç ayrı bölgeye bölünmüştü. Abhaz; Tskhum (Sohum) ve Bedia. XII. yüzyılda Abhaz ve Sohum tek bölge olarak birleştirilir ${ }^{3}$.

Sergey Anisimof, Sohum Kalesi'nin yedinci asırda tahminen Miletliler tarafından bir koloni olarak kurulduğunu, eski adının "Dioskourios" olduğunu yazar. Müellif Romalıların buraya Sebastapolis, Gürcülerin ise Tuhumi dediklerini ifade eder. Osmanlı fethini 1455 'e tarihlendiren kaynak, Osmanlıların şehre önce "Su-kum Kale" sonra ise "Sohum" dediğini ifade edilir".

Cenevizliler 13-14 yüzyıllarda Küçük Asya'da kurdukları ticaret kolonilerine Karadeniz sahillerini de katmıştı. Cenevizlilerin Kefe'den (Caffa) Sohum'a (Sebastapolis) kadar uzanan topraklarda 39 ticaret kolonisi bulunmakta idi. Sebastapolis'te köle ticareti ile uğraşan Megrelliler, Ermeniler, Yahudiler ve Müslümanlar yaşıyorlardı. En değerli ticaret metaı köleler idi. Bölge halklarından olan Çerkesler, yaptıkları mücadelelerde ele geçirdikleri insanları köle olarak Cenevizlilere satıyor hatta onlarla köle akınlarına çıkıyorlardı. ${ }^{5}$.

Osmanlı Sultanı II. Mehmed, Trabzon Rum Devleti ve Batı Gürcistan'daki devletlere sadakatlerini arz etmeleri ve kendisine yıllık haraç vermelerini emreden nameler göndermiş (1453), bu suretle Abhazya hâkimi I. Liparit Osmanlı hâkimiyetini tanımıştır. Fatih'in Karadeniz siyaseti kapsamında yürüttüğü askeri faaliyetler neticesinde Kafkasya'da fiilen ilk fethedilen yer Abhazya olmuştur. Kaptan-ı Derya Hamza Paşa komutasında 56 gemiden oluşan Osmanlı donanması

\footnotetext{
${ }^{2}$ Mirza Bala, "Gürcistan" mad, MEB, İslam Ansiklopedisi, C. 4, İstanbul 1978, s. 838.

${ }^{3}$ Timur Açugba, Kronolojik Abhazya Tarihi, (çev., Oktay Chkotug) İstanbul 2015, s. 27, 28.

${ }^{4}$ Sergey Anisimof, Kafkas Klavuzu (Çev. Binbaşı Sadık), İstanbul 1926, s. 103.

${ }^{5}$ Sadık Müfit Bilge, Osmanlı Çă̆ı'nda Kafkasya, 1454-1829 (Tarih-Toplum-Ekonomi), İstanbul 2015, s. 55, 58.
}

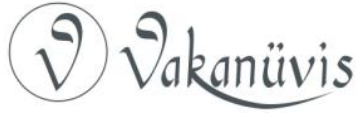


Haziran 1454'te Abhazya'nın merkezi olup Sebastapolis adlı Ceneviz ticaret kolonisinin de bulunduğu Sohum'u fethetmiştir ${ }^{6}$.

XVI. Yüzyılda Gürcistan toprakları Osmanlı-Safevî nüfuz mücadelesinin alanı olmuş, 1555 Amasya Antlaşması ile ülke taksim edilirken Eylül 1578'de Lala Mustafa Paşa'nın Tiflis'i fethetmesiyle birlikte Gürcü toprakları Osmanlı idaresine bağlandı ${ }^{7} .5$ Ekim 1578' de Sohum eyaleti kuruldu. Bir yıl sonra ise Faş boğazında Sohum Beylerbeyi Çerkes Haydar Paşa nezaretinde, Rion Nehrinin Karadeniz'e döküldüğü yerde Faş Kalesi inşa edildi. Amaç, hem Gürcistan kıyılarının güvenliğini temin etmek, bölgeye ve Şirvan'a erzak ve mühimmat sevkiyatını güvence altına almak hem de Abhazlar ve Megerellerin korsanlık faaliyetlerini engellemekti ${ }^{8}$.

\section{Sohum Kalesi'nin İnşâ Faaliyetleri}

Kafkasya'da yeniden inşa ya da tamir olunan kaleler için intiyaç duyulan gerek mühimmat, gerek yük hayvanı ve gerekse inşaatta çalıştırılan işçiler, bölgeye yakınlığı hasebiyle genellikle Trabzon, Erzurum, Giresun, Gönye, Ahıska gibi merkezlerden temin edilmekte idi. Yine kale muhafazalarında görevlendirilecek olan askerler de ağırlıklı olarak anılan bölgelerden istihdam ediliyordu. Bunun dışında Rumeli'den de toplanan mühimmat ve iaşe maddeleri genellikle Kili ve Bergos limanları vasıtasıyla bölgeye ulaştırılıyordu. Anadolu'dan gönderilen iş̧̧i, hayvan, mühimmat ve iaşe malzemelerinin de Karadeniz'e sahili bulunan Trabzon ve Giresun iskelelerinden kiralanan gemilerle Kafkasya'ya nakli gerçekleştirilmekte idi.

XVIII. yüzyılın ilk çeyreğinde tıpkı Faş Kalesi'nin inşası için geçerli olan sebeplerden dolayı Sohum'a da yeniden kale inşa etme ihtiyacı duyuldu. Maksat hem bölgedeki deniz ticaretini güvence altına almak hem de yerel Abhaz eşkıyalarının saldırılarını engellemek idi. Nitekim bu doğrultuda Abaza Beyi Rüstem'in idaresinde olan Sohum İskelesi'nde daha önceden kale var iken zamanla harap olmuştu. Bu

\footnotetext{
${ }^{6}$ Sadık Müfit Bilge, Osmanlı Çağı ..., s. 30, 96, 99.

7 İsmail Hakkı Uzunçarşılı, Osmanlı Tarihi, C.III, Kısım I, s. 59; Mahir Aydın, “Faş Kalesi”, Osmanlı Araştırmaları VI, İstanbul 1986, s. 69.

${ }^{8}$ Faş Kalesinin yapımı, geçirdiği tamirat ve ayrıntılı tarihçesi için bkz. Mahir Aydın, " Faş Kalesi", Osmanlı Araştırmaları VI, İstanbul 1986, s. 69;s. 67-138; Mahir Aydın, "Kaf Dağı'nda Türk Kalesi", Türklük Araştırmaları Dergisi, S. 20, s. 298-328.
}

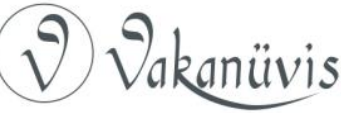


kalenin tekrar inşası ve tahkimi için Osmanlı idaresi harekete geçti. Keşif yapmak üzere Gedikli Ahmed Ağa, Hasan Reis ve hassa mimarlarından Muhammed Ağa görevlendirildi ${ }^{9}$. Söz konusu keşif neticesinde az miktarda askerle muhafaza edilebilecek kale ile lazım olan mühimmat ve cephanenin nerelerden temin edilebileceği de müzakere edildi.

Kalenin yapılması için gereken inşaat faaliyetleri şu şekilde tasarlanmıştı:

1. Mimar Mehmet tarafından keşfi yapılan kalenin yüzölçümü, tulen 1200, kadden 10, arzen 4 zira' olacak, kalenin toplam yüzölçümü 48.000 zira' kare olması hesaplandı.

2. Yıldız tarafına yapılacak tabya ve kuleler ile birlikte ve daire şeklinde 1200 zira' ve kaddi temeli 10 zira' ve arzen dört zira' olmak üzere yapılması,

3. Duvar örüldükten sonra üzeri toprakla doldurulup dipten lazım gelen yere hendek açılması, hendeğin önüne şaranpo dizilerek bina olunması,

4. Toplamda inşa olunacak kale duvarı dirseği hesabı üzere 48 bin zira'a ulaşacağı için bunun yapımında çalıştırılacak iş̧̧i ustalar arabalar temin edilip bunların üç aylık ücret ve masraflarının tahminen 30 bin 379 kuruş tutacağı,

5. 1723 yılında yapımına başlanmasına karar kılındı. Toprak kazılması ve şaranpo dizilmesinde çalıştırılmak üzere eyalet askerleri ve çektiri gemilerine muhtaç olunduğu, tüm bu işlerin yapımı için İstanbul'dan, beraberinde bir mimar ile bina emini atanması,

6. Nakliye için çektiri, kalyon ve fırkateler temin edilmesi,

7. Eğer taştan duvar yapılamazsa yine yukarıda belirtilen ölçülerde yıldız tarafına bir tabya yapılmak üzere olduğu gibi eski kale yerine şaranpolar dizilip kazılacak hendekten çıkan toprakla da şaranpoların içerisinin doldurulması,

8. Tüm bunların kış ayları gelmeden yapılması hesaplandı. İstanbul'dan gönderilecek üç kalfa ve 150 duvarcı; kalfalarıyla beraber 150 taş kırıcl; 25 kireç yapıcı, 11 sepetçi, lazım gelen keresteyi kesmek için balta ile birlikte 150 baltacı ve keza bina

${ }^{9}$ BOA, D.BŞM.BNE. d, 2/78 (1136 Ra. 25/ 23 Aralık 1723).

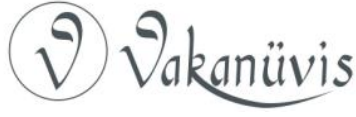


inşasında çalıştırılmak üzere 300 marangoz Trabzon, Gönye, Giresun, Gümüşhane, Erzurum, Ahıska ve o havalilerden toplamak için bir mübaşir tayin edilerek Gönye sancağı mutasarrıfı ve Gümüşhane emini İsmail Ağa vasıtasıyla her biri kendi alanında mahir işçiler Sohum'a gönderilmesi,

9. Söz konusu bölgelerden temin edilecek işçiler için beher çifti 15'er kuruş olmak üzere 200 çift manda satın alınması ve aynı bölgeden bu arabaları sürmesi için 150 arabacının tedariki,

10. İskele için lazım gelen on bin adet ağaç ve beher adedi 600 zira' olmak üzere şaranpoluk için lazım olan 8.000 kazığın söz konusu baltacılar vasıtasıyla iskele civarında bulunan dağlardan temini,

11. Beş lağımcı ve 10 taş yontucu, iki kömür yakıcı, 20 marangoz, iki su yolu yapıcının da hassa mimarbaşısı vasıtasıyla zanaatlarında ehil olmak şartıyla İstanbul'dan tedarik ve gemilerle Sohum'a gönderilmesi,

12. Tertip olunan mühimmattan mevcut olanlar Cebehane-i âmire ve Tersane-i âmire'den verilip olmayanların satın alınarak bunların da gemilerle bölgeye sevki,

13. 6.000 adet ağaç kürek ile 3.000 adet ıhlamur kesilerek İsmail Ağa vasıtasıyla bölgeye nakli,

14. Bir mübaşir görevlendirilerek Kırkkilise (Kırklareli), Vize ve Pınarhisar taraflarına gönderilip yüz adet araba için gerekli 400 adet araba tekerleklerinin burada yapılması, imal edilen tekerleklerden yapılacak arabalara numune için tekerlekleri ve mühimmatlarıyla beraber on adet öküz arabasının da yapılması

15. Söz konusu kazalardan 15 mahir arabacı temin edilerek yapılan araba ve tekerleklerle Bergos ìskelesinden gemilerle Sohum'a gönderilerek bina eminine teslimi,

16. Taş, kireç ve kereste nakli hizmetinde kullanılmak üzere Sinop iskelesinde kalyonlar inşasına memur Canım Hoca Mehmed Paşa vasıtasıyla on adet tombaz yaptırıp mühimmatıyla birlikte Sohum'a gönderilmesi,

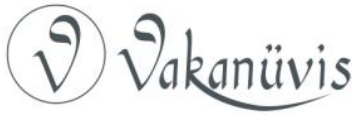


17. Sohum'da civardan kereste temini için ücretleri bina emininden verilmek üzere arabaların yapılması,

18. Sohum'a bina emini gidinceye dek temin edilecek işçilerle kale inşasında kullanılacak taşın kırdırılması ve kirecin hazırlanması,

19. Yukarıda bahsi geçen işleri yapılması ile ilgili mimar ve mübaşire yardımda bulunmak üzere bir mutemet tayin edilmesi ${ }^{10}$.

Hazırlanan keşif defterinde yapılması gerekenlerin uygulamaya konularak öncelikle değişik sınıflardan inşaatta çalışacak işçi temini yoluna gidildi. Nitekim taşçı, kireççi, baltacı ve sepetçi işçiler Erzurum, Trabzon, Ahısha, Gönye ve Batum taraflarından tertip olundu. Erzurum mütesellimi ve gümrük emini vekili Elhac Osman ve İstanbul'dan tayin olunan mübaşire gönderilen emirde, Sohum Kalesinin inşasında çalıştırılacak bu işçilerin Trabzon'a nakledilmesi istendi. Erzurum Valisi Kırımî Mustafa Paşa vasıtasıyla Erzurum eyaletinden temin edilen 218 işçinin ve Ahıska tarafından çeşitli sınıflardan toplanan 160, Gümüşhane'den toplanan 127 iş̧̧inin her birine peşinen Erzurum gümrük mukataası gelirinden 10'ar kuruş; Trabzon'dan toplanan 190 ve Gönye'den toplanan 94 işçinin her birine Trabzon ve Gönye gümrükleri mukataası gelirinden peşinen yine $10^{\prime}$ ar kuruş verilmesi emredildi $^{11}$. Kale inşasında çalıştırılmak üzere İstanbul'dan da Sohum'a iş̧̧i sevk edildi. Gönderilen kalfalar dahil toplam 64 işçi iç̧in üç aylık ücretleri olan 2360 kuruş hazine-i amireden tahsis edildi ${ }^{12}$.Trabzon'da pişirilecek peksimetlerin toplanması için Filibe ve Tatarbazarı kadı ve muhassıllarına gönderilen emirde, 2.500 adet çuval temin edilmesi istendi ${ }^{13}$.

Sohum Kalesi bina eminliği görevine Faş Kalesi bina emini olan Mustafa Bey getirildi. İnşaatta çalıştırılmak üzere Trabzon, Gönye, Erzurum, Gümüşhane ve civarından iş̧i temin edilerek kaleye gönderilmişti. İstanbul'dan da kaleye iş̧̧iler gönderildi. Hem İşçilerin

\footnotetext{
${ }^{10}$ BOA, D.BŞM.BNE. d, 2/78 (25 Ra. 1136/ 23 Aralık 1723); D.BŞM.BNE, 2/90.

${ }^{11}$ BOA, D.BŞM.BNE. d, 3/28 (22 C. 1136/ 18 Mart 1724).

${ }^{12}$ BOA, D.BŞM.BNE. d, 3/37 (15 B.1136/ 9 Nisan 1724); D.BŞM.BNE, 3/36.

${ }^{13}$ BOA, C.BH, $9 / 440$ (23 C. 1136/ 19 Mart 1734).
}

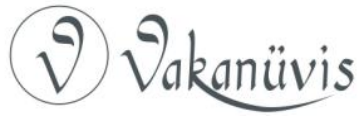


hem de taş, kereste, kireç gibi malzemelerin masrafı için Mustafa Bey'e toplamda yaklaşık 20 bin kuruş gönderildi ${ }^{14}$. Bir süre sonra Sohum Kalesi'ne bina emini olarak Erzincanî Yusuf Bey tayin edildi. Yüz günlük için kendisine bin kuruş peşinen verildi ${ }^{15}$. Kaptan-ı Derya Mustafa Paşa'ya gönderilen emirde, karayolu ile Trabzon'a gidecek olan Yusuf Bey'in buradan alınarak donanma gemilerinden biriyle Sohum'a ulaştırılması istendi ${ }^{16}$. Binaya tayin olunan iş̧̧ilerin ihtiyaçları olan peksimet ve ekmeğin yapımı için malzeme lazımdı. Yusuf Bey'le birlikte, Bu doğrultuda beş çift mükemmel meşin, on oturtma, iki adet açık çeşme, on adet musluk vs. ile beş çift sekban çadırı tahsis olundu. iki de kazan gönderilmesi düşünüldü. Yine işçiler için Elhac Nureddin vasıtasıla iki bin kantar peksimetin de gönderilerek bina eminine teslim edilmesi, baş muhasebe defterine kayıt olundu ${ }^{17}$.

Daha önceden Sohum Kalesi inşaatı masrafları için İstanbul'dan Faş bina emini iken ölen Mustafa Ağa'ya 5.000 kuruş gönderilmiş, kendinden sonra bina emini olan Abdullah Ağa vasıtasıyla, söz konusu para Sohum Kalesi bina eminine teslim edilmişti. Sohum Kalesi bina emini inşaat masrafları için bu meblağdan daha fazlasına intiyaç duyulduğunu ifade etti ${ }^{18}$. Hassa mimarlarından Mehmed Kalfa, Sohum Kalesi inşası için mimar tayin edildi. Kendisine 250 kuruş harcırah ve günlük bir buçuk kuruştan yüz günlük mukabili 150 kuruş verildi. Tayinat olarak ise günlük altı çift ekmek iki vukıyye et oldu ${ }^{19}$.

Sadece işçilerin temin edilmesi inşaat faaliyetlerinde yeterli değildi. Binada kullanılacak malzemenin nakli için yük hayvanına da ihtiyaç vardı. Bu doğrultuda Trabzon, Gönye ve Ahıska kadılarına ve bu iş için görevlendirilen Hüseyin ve bölgenin ileri gelenlerine gönderilen emirde, Sohum kalesi inşası için taş, kireç ve kereste naklinde kullanılmak üzere beher çifti 15 kuruştan 200 çift öküz temin edilmesi istendi. Bölgeye ulaştırılıp bina eminine teslim etmek üzere de mübaşir olarak görevlendirilen Dergâh-ı mualla gediklilerinden Seyyid Ali

\footnotetext{
${ }^{14}$ BOA, C.AS, 650/27323 (18 Za. 1136/ 19 Mart 1724).

${ }^{15}$ BOA, D.BŞM.BNE. d, 3/21 (16 C. 1136/ 12 Mart 1724); MAD, d, 9915, s. 133.

${ }^{16}$ BOA, D.BŞM.BNE. d, 3/18 (16 C. 1136/ 12 Mart 1724).

${ }^{17}$ BOA, D.BŞM.BNE. d, 3/13 (14 C. 1136/ 10 Mart 1724).

${ }^{18}$ BOA, D.BŞM.BNE. d, $1 / 60$.

${ }^{19}$ BOA, MAD, d, 9915, s. 363 (19 S. 1138/ 27 Ekim 1725).
}

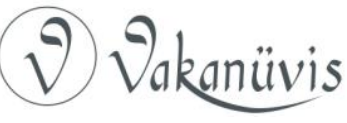


sağlayacaktı ${ }^{20}$. Öküzlerin bölgeye nakli ile ilgili Trabzon ve Gönye kadı ve mütesellimlerine gönderilen emirde, Trabzon, Rize, Gönye vs. iskelelerde gemi temin edilerek hayvanların Sohum'a sevk edilmesi istendi $^{21}$. Ayrıca kale inşasında görev yapacak iki fıçıcı da görevlendirildi. ${ }^{22}$

Kale inşası için İstanbul'dan üçer aylık ücretleri verilerek tayin olunan Batum, Gönye ve Gümüşhane bölgelerinden toplanan duvarcl, taş kırıcı, kireç yakıcı, baltacı ve marangozun da dahil olduğu 930 işçinin üçer aylık ücretleri 19.300 kuruş tutmuş olup Bina Emini Erzincanî Yusuf Bey'e 12.500 kuruş gönderilmişti. Kalan paranın ise bir mübaşir vasıtasıyla gönderilmesine karar verildi ${ }^{23}$.

Bölgedeki Abaza beylerinin de gönüllerini hoş tutmak gerektiğinden onlara da 1724 yılında İstanbul'dan on adet hilat gönderildi ${ }^{24}$. Merkeze bağlııklarını arttırmak amacıyla gönderilen bu hediyeler sadece bir defaya mahsus olmamış değişik zaman aralıklarında çeşitli türden hediyeler verilmeye devam etmiştir. Nitekim 1729 senesinde de Abaza beylerinden Rostom Bey'e 100, Yorgi Bey 80, Kerek Bey'e 50, Davud Bey 40, Ahtulı Beyine 40, Otar Bey'e 40'ar akçe günlük verildi. 1730' da ise sadece Rostom beyine günlük 100 ve Yorgi beyine günlük 80 akçe verildi. Ayrıca kale inşasında görev alan iş̧ilere de teşvik maksatlı gayretlerini arttırmak için maaşlarının dışında para da verilmekte idi ${ }^{25}$.

İnşaatta kullanılan taş, kireç vs. mühimmat nakli için burada yaptırılacak arabalara koşmak için karasığıra ihtiyaç vardı. Bunun için Kefe, Kerç ve Taman kadılarına gönderilen emirde, Sohum bina emininin göndereceği mübaşir vasıtasıyla lazım olan hayvanların temin edilerek gemilerle Sohum'a gönderilmesi istendi ${ }^{26}$. Diğer yandan Sinop iskelesinde kalyonlar inşasına memur Canım Hoca Mehmed Paşa'ya gönderilen emirde, Faş, Soğucak ve Sohum'da inşa edilen kalelerde ihtiyaç duyulan taş, kireç vs. mühimmatın naklinde kullanılmak üzere

\footnotetext{
${ }^{20}$ BOA, MAD, d, 9915, s. 84 (22 S. 1138/ 30 Ekim 1725).

${ }^{21}$ BOA, MAD. d, 9915, s. 85, 188, 212 (22 S. 1138/ 30 Ekim 1725).

${ }^{22}$ BOA, D.BŞM.BNE. d, 3/36 (15 B. 1136/ 9 Nisan 1724).

${ }^{23}$ BOA, D.BŞM.BNE. d, 3/20 (16 C. 1136/ 16 Mart 1724).

${ }^{24}$ BOA, D.BŞM.BNE. d, 3/19 (16 C. 1136/ 16 Mart 1724)

${ }^{25}$ BOA, MAD, d, 2455, s. 70-75.

${ }^{26}$ BOA, AE, SAMD.III, 109/10722 (9 B. 1139/ 2 Mart 1727).
}

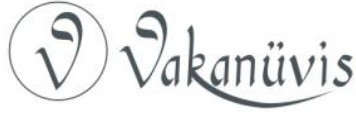


Faş kalesine 20, Soğucak ve Sohum kalelerine onar olmak üzere toplam 40 tombaz gemisi gönderilmesi istendi ${ }^{27}$.

Yapılan hazırlıklar ve yürütülen inşaat faaliyetleri neticesinde, Bina Emini Yusuf Bey zamanında kalede birçok yapı vücuda getirildi. Buna göre aşağıdaki tabloda yapılan işlerin ayrıntısı verilmiştir ${ }^{28}$.

\begin{tabular}{|l|l|l|l|l|}
\hline İnşa olunan yapı & tulen & Arzen & Kadden & Zira' \\
\hline $\begin{array}{l}\text { Kalede inşa olunan } \\
\text { şaranpolar, }\end{array}$ & & $\begin{array}{l}\text { Dağ tarafı 760 } \\
\text { Deniz tarafı 340 } \\
\text { Şaranpo kazığı } \\
\text { yüksekliği deniz } \\
\text { tarafı) 3,5 } \\
\text { Kara tarafı: 7 }\end{array}$ \\
\hline $\begin{array}{l}\text { Taş temel üzerine toprak } \\
\text { dolgu ile yapılan cami }\end{array}$ & 20 & 18 & 7 & \\
\hline $\begin{array}{l}\text { (kadı müftü) Kasım } \\
\text { Efendi'ye yapılan hane } \\
\text { temeli }\end{array}$ & 16 & 16 & 6 & \\
\hline $\begin{array}{l}\text { Yedinci Sekban Kışlası } \\
\text { Temeli }\end{array}$ & 24 & 8 & 4 & \\
\hline Cebeciler Kışlağı temeli & 16 & 8 & 4 & \\
\hline Topçu Kışlası & 22 & 9 & 4 & \\
\hline Altıncı Cemaat Kışlası & 24 & 8 & 4 & \\
\hline Fırın ç & 12 & 10 & 4 & \\
\hline Fırın çatısı & 18 & 16 & 5 & \\
\hline $\begin{array}{l}\text { Eski Kale duvarı üzerine } \\
\text { inşa olunan kovuş Ambarı }\end{array}$ & 96 & 10 & 5 & \\
\hline $\begin{array}{l}\text { Eski kale duvarında tamir } \\
\text { olunan yerler }\end{array}$ & 12 & 5 & 9 & \\
\hline $\begin{array}{l}\text { Kale dışında ırmak } \\
\text { üzerinde yapılan köprü }\end{array}$ & 22 & 6 & 6 & \\
\hline $\begin{array}{l}\text { Kovuş ambarının önünde, } \\
\text { deniz } \\
\text { üzerine yapılan Tahta-bûş }\end{array}$ & 10 & 6 & 4 & \\
\hline
\end{tabular}

${ }^{27}$ BOA, C.BH, $9 / 440$ (15 C. $1136 / 11$ Mart 1724).

${ }^{28}$ BOA, D.AMH.d 24788, s. 4-12. 


\begin{tabular}{|c|c|c|c|}
\hline $\begin{array}{l}\text { Kalenin kuzeyinde yapılan } \\
\text { Tabya }\end{array}$ & 6 & 6 & 6 \\
\hline $\begin{array}{l}\text { Denizin batı kısmında } \\
\text { şaranpolar üzerine inşa } \\
\text { olunan tabya }\end{array}$ & 6 & 6 & 6 \\
\hline $\begin{array}{l}\text { Bina emini hizmetkârları } \\
\text { için yapılan kulübe } \\
\text { Katip için } \\
\text { Hizmetkârlar için }\end{array}$ & 6 & $\begin{array}{l}4 \\
4\end{array}$ & $\begin{array}{l}3 \\
2,5\end{array}$ \\
\hline $\begin{array}{l}\text { Kale dışına inşa olunan } \\
\text { Zahire ambarı }\end{array}$ & 16 & 16 & \\
\hline
\end{tabular}

İņ̧aat için lazım olan kereste bölgeden temin edilmiş, taş gereksinimi ise eski kale temelinden sökülerek sağlanmıştı ${ }^{29}$.Kalenin kireç gereksinimini karşılamak üzere her bir arabaya beşer kantar kireç yüklenip 1859 araba ile Taşık'tan Gümüştaş İskelesi yoluyla kaleye taşındı $^{30}$. Yoğun geçen inşaat faaliyetleri sırasında işçilerden üçü vefat etmiş, 31'i i̇stanbul'a dönmüş, 13 işçi de Sohum'da alıkonulmuştur ${ }^{31}$.

Bina emini Yusuf Bey zamanında yapılan inşaatın masrafı 8.529 kuruş104 akçeye mal olmuştur. Bina eminine masraf için toplamda 14.100 kuruş verilmişti ${ }^{32}$. Yusuf Bey'den sonra bina eminliğine Mustafa Ağa'nın atandığını görmekteyiz ${ }^{33}$. Mustafa Ağa, selefi Yusuf Bey'den 19.863 kile un, 52. 632 kıyye peksimet ve 18.862 kıyye buğday devraldi ${ }^{34}$.

Başbakanlık Osmanlı Arşivinde 1725-1726 yıllarına ait, Faş Muhafızı Mirza Mehmet Paşa nezaretinde Bina Emini Mustafa Ağa tarafından yürütülen kale inşası faaliyetlerini gösteren bir defter mevcuttur. Söz konusu defterde her ay için çeşitli sınıflardan çalıştırılan usta, kalfa ve

\footnotetext{
${ }^{29}$ BOA, D.AMH.d, 24788, s. 14.

${ }^{30}$ BOA, MAD, d, 2455, s. 66-69.

${ }^{31}$ BOA, D.AMH.d, 24788, s. 14.

${ }^{32}$ BOA, D.AMH.d, 24788, s. $18,19$.

${ }^{33}$ BOA, D.AMH.d, 24788, s. 21.

${ }^{34}$ BOA, D.AMH.d, 24788, s. 12.
} 
işçilerin aylık ücretlerini gösteren mali kayıtlar yer almaktadır. Marangoz, taş kırıcı, demirci, bıçkıcı, taş yonucu, kireç yakıcı, tuğlacı, hamamcı, arabacı, rençber, öküz çobanı, hazineci kâtip, mutemet, Abaza kabilelerinden temin edilen kılavuzlar, tombazcı, vs. gibi iş erbabı için yevmiye akçe hesabından ödeme cetvelleri yer almaktadır. Günlük olarak kalfalar 60 , ustalar 40 , işçilere ise 20 akçe almakta idiler $^{35}$.

Eylül 1725-Temmuz 1727 yılları arasında kale inşasında görev alan ve sayıları aşağı yukarı pek değişmeyen çeşitli sınıftan görevlilerin listesi şu şekildedir ${ }^{36}$ :

\begin{tabular}{|l|l|l|l|l|}
\hline Sınıfı & Kalfa & Usta & İşçi & Toplam \\
\hline Marangoz & 1 & & 20 & 21 \\
\hline Taş kırıcı & 1 & & 20 & 21 \\
\hline Demirci & & 1 & 3 & 4 \\
\hline Bıçkıcı & & & 2 & 2 \\
\hline Kireçci & 1 & & 12 & 13 \\
\hline Kiremitçi & 1 & & 13 & 14 \\
\hline Hamamcı & 1 & & 1 & 2 \\
\hline Arabacı & & & 2 & 2 \\
\hline Rençber & & & 7 & 7 \\
\hline Öküz çobanı & & & 5 & 5 \\
\hline Hazineci & & & 2 & 2 \\
\hline Katip & & & 2 & 2 \\
\hline Mutemed & & & 6 & 6 \\
\hline Kılavuz (Abaza kabilesinden) & & & 2 & 2 \\
\hline Tombazcı & & & 5 & 5 \\
\hline Toplam & 5 & 1 & 102 & 108 \\
\hline
\end{tabular}

Yusuf Bey'in vefatı üzerine bina eminliğine eski Edirne bostancıbaşısı Mustafa Ağa tayin olundu. Yusuf Bey'in kendisine gönderilen paranın bir kısmın bina inşasında harcamadığının tespit edilmesi üzerine Faş Muhafızı Mirza Mehmet Paşa'ya gönderilen bir

\footnotetext{
${ }^{35}$ BOA, MAD, d, 2455.

${ }^{36}$ BOA, MAD, d, 2455.
} 
emirde, söz konusu paranın Yusuf Bey'in adamlarından tahsil edilerek Bina Emini Mustafa Ağaya teslim edilmesi istendi. İstanbul'dan Mustafa Ağaya gönderilen emirde ise bir an evvel görev mahalline giderek kale inşaatının tamamlanması istendi ${ }^{37}$. Mustafa Ağa zamanında da inşaat faaliyetleri yoğun şekilde devam etti. 1724 yılında İbrahim Halife mimar, İsmail Ağa ise kale nazırı tayin edildi ${ }^{38}$.

Daha önce Yusuf Bey zamanında, ölçüleri de ilgili kısımda verilen, kârgir cephane, Tophane mühimmat mahzeni; iki odalı, kiler, mutfak, kenef ve sofalı cebeciler kışlası; aynı özelliklerde Topçular kışlası; iki odalı, mutfaklı, kenefli topçubaşı konağı; 11 odalı, kenef, mutfak ve sofalı Cebecibaşı Konağı; 13 odalı yeniçeri ağası konağı; dokuz odalı Altı Bölük kışlası; dokuz odalı Yedi Sekban kışlası; yedi odalı yeniçeri çorbacısı hanesi; 780 zira'kare hamam; iki odalı Nevbethne; 12 odalı müftü/kadı konağı; beşer odalı imam ve müezzin haneleri; iki odalı tabip ve mektep hanesi; 29 odalı muhafız konağı; bir adet ayak kasrı; değirmen, Peksimet ambarı, 15 odalı Emin Ağa hanesi, iki odalı nazır ağa konağı; sekiz odalı mimar, kâtipler, mu'temedler ve matbah nazırı haneleri; varoş çayı üzerine köprü; mîri öküzler için dört odalı ahır; Rüstem Bey için konak; cami için ahşap minare; civardaki diğer bir çay üzerine iki adet köprü; ameleler için yedi odalı hane; mutemet için bir oda; bir adet cephanelik ve mahzeni; Arpa ambarı; Taşlık mevkiinde yarısı kârgir köprü; Taşlık civarında bir odalı öküz ahırı; işçiler için mutfak yapılmıştı. Böylelikle Bina Emini Yusuf Bey'den sonra Mustafa Ağa zamanında 1725 Eylülünden 1729 Ekim ayına kadar Sohum Kalesi inşası tamamlanmış olur ${ }^{39}$.

1729 yılında Sohum Kalesi Bina Emini Mustafa Ağa ve Hassa Mimarlarından İbrahim Halife Zamanından Tamamlanan Kale bina ve yapıları $^{40}$

\footnotetext{
${ }^{37}$ BOA, C.AS, 585/24639 (8 Ra. 1138/ 14 Kasım 1725).

${ }^{38}$ BOA, MAD. d, 2455, s. 64, 74.

${ }^{39}$ BOA, D.BKL. d, 32442, s. 4-5.

${ }^{40}$ BOA, MAD. d, 1471 (6 Za 1141/ 3 Haziran 1729); BOA, D. BKL, 32442, s.2.
}

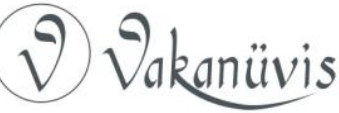




\begin{tabular}{|c|c|c|c|c|}
\hline İnşa Olunan Yapı & Tulen & Kadden & Arzen & $\begin{array}{l}\text { Toplam/ } \\
\text { zira'kare }\end{array}$ \\
\hline $\begin{array}{l}\text { Emin Ağa Tabyası } \\
\text { Hisar-ı peçe }\end{array}$ & $\begin{array}{l}68 \\
68\end{array}$ & $\begin{array}{l}12 \\
3,5\end{array}$ & $\begin{array}{l}5 \\
1\end{array}$ & $\begin{array}{l}4.080 \\
212,5\end{array}$ \\
\hline Taş karakolhane & 4 & 5 & 4 & 30 \\
\hline $\begin{array}{l}\text { Emin Ağa Tabyasının iç } \\
\text { tarafında bölme duvarı }\end{array}$ & 17 & 6 & 1 & 140 \\
\hline $\begin{array}{l}\text { Emin Ağa Tabyası denize yakın } \\
\text { olduğu için tabyayı korumak } \\
\text { için önüne yontma taş duvar } \\
\text { ve önü topaç kazıklı iskele }\end{array}$ & 15 & 2 & 2 & 60 \\
\hline $\begin{array}{l}\text { Emin Ağa Tabyasından Kûh-ı } \\
\text { Elbruz Kapısına kadar Duvar } \\
\text { Hisarı-ı peçe }\end{array}$ & $\begin{array}{l}16 \\
16\end{array}$ & $\begin{array}{l}10 \\
2,5\end{array}$ & $\begin{array}{l}4 \\
1\end{array}$ & $\begin{array}{l}640 \\
40\end{array}$ \\
\hline $\begin{array}{l}\text { Kûh-ı Elbruz Kapısından } \\
\text { Topçular Tabyasına kadar eski } \\
\text { temel üzerine kademe duvarı } \\
\text { Hisar-ı Peçe }\end{array}$ & 160 & 2,5 & 4 & 4.800 \\
\hline $\begin{array}{l}\text { Topçular Tabyası } \\
\text { Hisar-ı Peçe }\end{array}$ & $\begin{array}{l}58 \\
58\end{array}$ & $\begin{array}{l}12 \\
2,5\end{array}$ & $\begin{array}{l}5 \\
1\end{array}$ & $\begin{array}{l}3.480 \\
180\end{array}$ \\
\hline Taş Yonma Karakolhane & 4 & 5 & 4 & 80 \\
\hline $\begin{array}{ll}\text { Topçular Tabyasından } & \text { Uğrun } \\
\text { Kapısına kadar eski temel } \\
\text { üzerine kademe duvarı } \\
\text { Hisar-ı Peçe }\end{array}$ & 180 & 2,5 & 4 & $\begin{array}{l}7.200 \\
420\end{array}$ \\
\hline $\begin{array}{lrr}\text { Uğrun } & \text { Kapısından } & \text { Zindan } \\
\text { tabyasına } & \text { kadar } & \text { kademe } \\
\text { duvarı } & & \\
\text { Hisar-ı Peçe } & & \end{array}$ & $\begin{array}{l}40 \\
30\end{array}$ & $\begin{array}{l}11,5 \\
2,5\end{array}$ & $\begin{array}{l}4 \\
1\end{array}$ & $\begin{array}{l}184 \\
85\end{array}$ \\
\hline $\begin{array}{l}\text { Zindan Tabyası } \\
\text { Hisar-ı Peçe }\end{array}$ & $\begin{array}{l}60 \\
60\end{array}$ & $\begin{array}{l}12 \\
2,5\end{array}$ & $\begin{array}{l}5 \\
1\end{array}$ & $\begin{array}{l}3.600 \\
37\end{array}$ \\
\hline Taş yonma Karakolhane & 4 & 5 & 4 & 35 \\
\hline $\begin{array}{l}\text { Zindan Tabyasından İslambol } \\
\text { Kapısına kadar kademe duvarı } \\
\text { Hisar-ı Peçe }\end{array}$ & $\begin{array}{l}94 \\
94\end{array}$ & $\begin{array}{l}11,5 \\
2,5\end{array}$ & $\begin{array}{l}4 \\
1\end{array}$ & $\begin{array}{l}4.324 \\
235\end{array}$ \\
\hline $\begin{array}{l}\text { İslambol/Âsitane/istanbul } \\
\text { Kapısından } \quad \text { Ağa } \quad \text { Tabyasına }\end{array}$ & 40 & 11,5 & 4 & 1.840 \\
\hline
\end{tabular}




\begin{tabular}{|c|c|c|c|c|}
\hline $\begin{array}{l}\text { kadar kademe duvarı } \\
\text { Hisar-ı Peçe }\end{array}$ & 40 & 2,5 & 1 & 100 \\
\hline $\begin{array}{l}\text { Ağa Tabyası } \\
\text { Hisar-ı Peçe }\end{array}$ & $\begin{array}{l}68 \\
68\end{array}$ & $\begin{array}{l}12 \\
2,5\end{array}$ & $\begin{array}{l}5 \\
1\end{array}$ & $\begin{array}{l}4.080 \\
212,5\end{array}$ \\
\hline Taş yonma Karakolhane & 4 & 5 & 4 & 35 \\
\hline $\begin{array}{l}\text { Tabyanın iç tarafında bölme } \\
\text { duvarı }\end{array}$ & 17 & 6 & 1 & 106 \\
\hline $\begin{array}{l}\text { Ağa Tabyasından Emin Ağa } \\
\text { Tabyasına kadar duvar } \\
\text { Hisar-ı Peçe }\end{array}$ & $\begin{array}{l}180 \\
180\end{array}$ & $\begin{array}{l}11,5 \\
2,5\end{array}$ & $\begin{array}{l}4 \\
1\end{array}$ & $\begin{array}{l}8.280 \\
450\end{array}$ \\
\hline $\begin{array}{l}\text { Âsitane Kapısı } \\
\text { Hisar-ı Peçe }\end{array}$ & $\begin{array}{l}10 \\
10\end{array}$ & $\begin{array}{l}12 \\
2,5\end{array}$ & $\begin{array}{l}11 \\
1\end{array}$ & $\begin{array}{l}1.320 \\
25\end{array}$ \\
\hline İki tarafa köprüleme ayak & 3 & 3 & 3 & 54 \\
\hline $\begin{array}{l}\text { Kûh-ı Elbruz Kapısı } \\
\text { Hisar-ı Peçe }\end{array}$ & $\begin{array}{l}10 \\
10\end{array}$ & $\begin{array}{l}12 \\
2,5\end{array}$ & $\begin{array}{l}11 \\
1\end{array}$ & $\begin{array}{l}1.320 \\
25\end{array}$ \\
\hline İki tarafa köprüleme ayak & 3 & 3 & 3 & 54 \\
\hline Kûh-ı Elbruz Kapısının çatısı & 15 & & 17 & 255 \\
\hline Zindan Tabyası çatısı & 22 & & 27 & 864 \\
\hline Zindan Tabyası döşemesi & & & & 1500 \\
\hline $\begin{array}{l}\text { Tabyalar ile Âstane } \\
\text { arasında top keşide } \\
\text { civara merdiven }\end{array}$ & 15 & & 3,5 & 262,5 \\
\hline $\begin{array}{l}\text { Daha önceden inşa olunan } \\
\text { camiye minare }\end{array}$ & 4 & & 3,5 & $\begin{array}{l}84 \\
\text { Bilezik } \\
\text { devri: } 6 \\
\text { Toplam: } \\
104\end{array}$ \\
\hline Bilezik tuğlası & 6 & 18 & 2 & 317 \\
\hline Köprü & 45 & & 5 & 225 \\
\hline Kiremit Fırını & 5 & 6 & 5 & $\begin{array}{l}132 \\
\text { Sundurma: } \\
270 \\
\text { Toplam: } \\
402\end{array}$ \\
\hline $\begin{array}{l}\text { Kalenin tabyaları, duvarları, } \\
\text { toplamı }\end{array}$ & & & leri & 53.404 \\
\hline
\end{tabular}


1723'ten 1729'a kadar devam eden inşaat/tamirat faaliyetleri süresince kalenin yapımı için çıkarılan ilk keşif defterinden sonra her bina emini değişiminde bir önceki bina emini zamanında yapılan faaliyetler yine bir keşifle kayıt altına alınmakta idi. Ödenekler ve harcamalar karşılaştırılarak aradaki fark ortaya konulmakta ve usulsüzlük ya da eksiklik görüldüğünde bunun giderilmesi için değişik yöntemlere başvurulmakta, böylece devlet hazinesinin zarara uğraması engellenmekte idi.

3 Haziran 1729 tarihinde İnşası tamamlanan kalede dört tabya ve üç kapı bulunmakta idi: Emin Ağa ve Ağa tabyalarının büyüklükleri aynı olmakla birlikte diğer iki tabyadan daha geniş; Topçular ve Zindan tabyaları da aşağı yukarı aynı genişliktedir. Kalede yer alan üç kapı ki adları tablolarda da belirtildiği üzere Kûh-ı Elbruz Kapısı (Kafkas Dağları'na bakan yönde); Uğrun Kapısı ve Âsitane kapısı ya da diğer adıyla İslambol Kapısı. Dikkat çeken husus ise özellikle bu dönemde İstanbul için kullanılan "İslambol" tabirinin sadece yazışmalarda değil yapılarda da kullanılması olmuştur. Söz konusu kapıların üzerine çatılar da inşa edilmiştir.

Yapılan keşifte mühürleri bulunan kale ileri gelenleri ise defterde geçen sıraya göre aşağıdaki isimler olmuştur:

Sekban Çorbacısı Halil,

Dergâh-ı âli Topçubaşı Vekili Abdullah,

Dergâh-ı âli Cebecibaşı Vekili Hasan,

Yeniçeri Ağası Vekili Hasan,

Kadı Kasım,

Sohum Kalesi Muhafızı Mir Ali Arslan,

Beşliyan-ı evvel Ağası Ali,

Beşliyan-ı sâni Ağası Mehmed,

Yerli Topçubaşı Baba Süleyman,

Azeban Ağası Elhac Abdullah,

Gönüllüyan-ı Yesar Ağası Ahmed,

Gönüllüyan-ı Yemin Ağası Ebubekir,

Kale Dizdarı Mehmed,

Mimar Halifesi İbrahim, 
Hendek Ağası Mehmed ${ }^{41}$.

Aşağıdaki tabloda keşifle maliyetleri tespit edilen (tabyalar ve ana duvarlar hariç) yapılar yer almaktadır ${ }^{42}$.

\begin{tabular}{|l|l|}
\hline Yapılan Bina & Tutar/akçe \\
\hline Cami-i şerif & 196.760 \\
\hline Kargir minaresi & 143.600 \\
\hline Kargir çifte odalar & 353.615 \\
\hline Kargir cebehane & 463.872 \\
\hline Tophane & 239.70 \\
\hline Ara Toplam & $\mathbf{1 1 8 1 8 1 7}$ \\
\hline Topçular kışlası & 69.440 \\
\hline Topçubaşı konağı & 393.00 \\
\hline Cebeciler kışlası & 115.060 \\
\hline Cebecibaşı konağı & 649.00 \\
\hline Yeniçeri ağası konağı & 181.680 \\
\hline Ara Tolam & 1652197 \\
\hline $\begin{array}{l}\text { Altıncı cemaatin sakin olduğu dergah-ı ali yeniçeri } \\
\text { kıslası }\end{array}$ & 140.500 \\
\hline $\begin{array}{l}\text { Yedinci sekbanların sakin olduğu dergah-ı ali } \\
\text { yeniçeri kışlası }\end{array}$ & 114.340 \\
\hline Rehinler odası ve nevbethanesi & \\
\hline Çorbacı konağı hanesi & 65500 \\
\hline Kargir hamam & 17340 \\
\hline Ara Toplam & 588680 \\
\hline Müftü ve kadı konağı & $\mathbf{2 5 7 . 8 5 5 7}$ \\
\hline İmam hanesi & 153.520 \\
\hline Çay üzerinde yapılan hızar (çit) & 45330 \\
\hline Müezzin hanesi & 39692 \\
\hline Mekteb ve tabibhanes & 17360 \\
\hline Ara Toplam & 19020 \\
\hline Muhafız konağı & $\mathbf{2 8 5 3 4 7 9}$ \\
\hline Bina üzerinde gezer ayak kasrı & 257340 \\
\hline Askeri tayinatlar için ekmek fırını & 6000 \\
\hline & 70190 \\
\hline
\end{tabular}

${ }^{41}$ BOA, MAD. d, 1471, s. 71 (6 Za. 1141/ 3 Haziran 1729).

${ }^{42}$ BOA, MAD. d, 1471, s.70-71 (6 Za. 1141/ 3 Haziran 1729). 


\begin{tabular}{|l|l|}
\hline Bir bab Horos değirmeni & 3880 \\
\hline Müceddeden yapılan peksimed ambarı & 30040 \\
\hline Ara Toplam & 3248929 \\
\hline Emin Ağanın konağı & 62955 \\
\hline $\begin{array}{l}\text { Tahtel iktiza müceddeden yapılan emin ağa } \\
\text { konağı }\end{array}$ & 36100 \\
\hline Nazır ağanın ve mimarın ve mutemedlerin odaları & 70980 \\
\hline Varoşta yapılan iskele-i kebir & 54400 \\
\hline Çay üzerinde üç defa yapılan köprü & 96000 \\
\hline Ara Toplam & 3569364 \\
\hline Kiremithane & 25060 \\
\hline Varoş yolunda yapılan köprü & 8160 \\
\hline Öküz ahırı & 14300 \\
\hline Defa öküz ahırı & 12250 \\
\hline Defa öküz ahırı & 19600 \\
\hline Ara Toplam & 3648734 \\
\hline $\begin{array}{l}\text { Kalenin varoşunda Abaza Meliki Rüstem Beyin } \\
\text { geldiğinde sakin olmak için yapılan hane }\end{array}$ & 6850 \\
\hline Varoşta yapılan kenef (iki aded) & 2700 \\
\hline Tahta minare & 6300 \\
\hline Kanlı çay üzerinde yapılan çifte köprü & 40960 \\
\hline $\begin{array}{l}\text { Kireç toplanan Gümüştaş iskelesinde üç defa } \\
\text { yapılan iskele }\end{array}$ & 66720 \\
\hline Ara Toplam & $\mathbf{3 7 7 2 2 6 4}$ \\
\hline $\begin{array}{l}\text { Kireç hark olunan taşlıkta imal olunan çeşitli } \\
\text { meslekten işçiler için yapılan odalar }\end{array}$ & 15400 \\
\hline Cebehane hıfı için yapılan oda bahası & 2400 \\
\hline Taşlık tamirlerine yapılan oda & 3200 \\
\hline Taşlıkta yapılan nısf kargir köprü & 97680 \\
\hline Taşlıkta amelelerin önlerine yapılan ekmek fırını & 16800 \\
\hline Taşlıkta imal olunan öküz ahırı & 28320 \\
\hline Ara Toplam & 3919264 \\
\hline Defa taş öküz ahırı kalede yapılmıştır & 5460 \\
\hline Ara Toplam & 3941524 \\
\hline $\begin{array}{l}\text { Hedm olunan yapıların ekserinde } \mathrm{n} \text { maada ihraç } \\
\text { olunan toprak vs. }\end{array}$ & 30.000 \\
\hline
\end{tabular}




\section{Genel toplam}

3911524

Incelediğimiz keşif defterinin devamında daha önceden inşa edilen cami, kışlalar, fırın, cephanelikler, konaklar, ambarlar vs. yeniden ölçüleriyle birlikte zikredilmektedir.

İşçilerin Elbruz dağlarından temin ettikleri kerestelerin kaleye daha kolay nakli için bölgedeki çay üzerine köprüler de inşa edilmiştir (tulen 45 , arzen 5 zira' $^{\prime 43}$. Abaza Beyi Rüstem, adamları ile birlikte kaleyi ziyarete geldikleri zaman misafir olarak konaklamaları için bir hane de yapılmıştır ${ }^{44}$.

Kale inşası devam ederken masraflar için Bina Emini Yusuf Bey'e önce 12.500 ardından 7.500 kuruş olmak üzere toplam 20.000 kuruş gönderildi. Bölgede hüküm süren Abaza beylerine de çeşitli türden hediye ve mühimmat gönderildi. İnşaatta çalışan işçilerin iaşesi içinde İstanbul, Bergos ve Trabzon iskelelerinden 9.000 kile un ile 3.000 kantar peksimet gönderildi ${ }^{45}$. İnşaat faaliyetlerinde taş ve kireç naklinde kullanılmak üzere Şehtiye gemisi tedarikinde bulunması da Faş muhafızından istendi ${ }^{46}$.

Faş, Sohum ve Soğucak kaleleri hizmetinde bulunanlar için 1800 kantar peksimet ihtiyacı, Silistre ibrail ve Kili'den gelenlerle karşılanmış, miktarın eksik kalması üzerine Bergos'tan gelen peksimetle açık kapatılmışı. Aynı kaleler için 1800 kile un da Trabzon iskelesi ambarlarından temin ile gemilerle bölgeye nakli için Trabzon Gümrük Emini ve mütesellimi Ömer'e emir gönderildi ${ }^{47}$.

Bergos iskelesinde bulunan satın alma mübaşirine gönderilen emirde, 1726 senesi için Faş kalesi için 10 bin Sohum Kalesi için altı bin

\footnotetext{
${ }^{43}$ BOA, MAD. d, 1471, s. 57.

${ }^{44}$ BOA, MAD. d, 1471, s. 62.

${ }^{45}$ BOA, C.AS, 585/24639 (8 Ra. 1138/ 14 Kasım 1725).

${ }^{46}$ BOA, D.BŞM, BNE, d, 15889, s. 2 (8 Ra. 1138/ 14 Kasım 1725); BOA, MAD, d, 9915, 134.

${ }^{47}$ BOA, C.AS, 726/30438 (18 Za. 1138/ 18 Temmuz 1726).
}

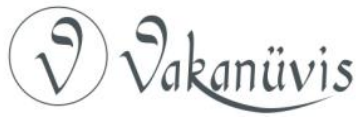


kile unun gemilere yüklenerek kalelerin bina eminlerine teslim edilmesi istendi ${ }^{48}$.

Bölgenin iaşe ve asker ihtiyaçlarını karşılamak için Anadolu ve Rumeli dışında Kırım'dan da temin yoluna gidilmekte idi. Nitekim 1733 yılında ise Faş, Sohum ve Soğucak kalelerindeki askerlerin iaşesi için lazım olan buğdayın Kefe havalisinden temin ve nakliyesini sağlamak üzere Mehmed Ağa mübayaacı olarak atandı ${ }^{49}$.

Faş Kalesi'ne başbuğ olarak Tersane kethüdası Musa Paşa atandı. Hizmetine tayin olunan Çekdirir gemilerinden başka kalenin muhafaza ve bina hizmetlerinde kullanılmak için onar adet firkate ve kancabaş gemileri görevlendirildi. Soğucak Kalesi'ne Süleyman Paşa başbuğ tayin edilerek kendisine beşer adet firkate ve kancabaş tahsis edildi; Sohum Kalesi'ne ise Salih Paşa başbuğ olarak atandı. Paşanın hizmetine beşer adet firkate ve kancabaş verildi. Toplamda 20'şer adet firkate ve Kancabaş gemileri görevlendirildi. Bunların ücretleri İstanbul'dan yola çıktıkları sırada verildi. İstanbul'dan görev yerlerine gittiklerinde leventlere dağıtılmak üzere de 5000 kuruş gönderildi. Faş kalesi etrafı birbirlerine muhalif Gürcü ve Abaza eşkıyası olduğundan bölge halkına kışın zahire nakli için oraya gidip gelen tüccarın muhafazası maksadıyla on adet İşkampavye gemilerine ihtiyaç olup bunlara da bir kaptan ve başbuğ tayin edilmesi elzemdi. Bu doğrultuda 1726 yılında o bölgeden merkeze haber getiren Bıyıklı Mehmet kaptan başbuğ tayin edildi. Ayrıca Baba Ali Kaptan'dan da Faş açıklarında geşt-ü güzar ederek bölgenin muhafazasına dikkat etmesi istendi ${ }^{50}$.

Trabzon kadısına ve ambar emini Mustafa'ya gönderilen bir emirde, Faş, Sohum ve Soğucak kalelerinin binası hizmetine memur olan dokuz adet çekdirir gemilerinin bölgede kışlamak üzere memur edildiğinden her bir gemilerde yer alan görevli personel için gemi başına 200'er kantardan toplam 1800 kantar peksimet ve 200'er kileden toplam 1800 kile un verilmesi gerektiği belirtildi. Peksimedin 270 kantarının Silistre, İbrail ve Kili'den naklolunan peksimetten verildiği geri kalan 1130 kantarının ise Tuna ve Bergos iskelelerinde pişirilen peksimetten

\footnotetext{
${ }^{48}$ BOA, IE, ML, 121/11475 (2 B. 1138/ 6 Mart 1726).

${ }^{49}$ BOA, AE.SMHD. I, 233/18711 (22 C. 1146/ 30 Kasım 1733).

${ }^{50}$ BOA, C.AS, 726/30438 (18 Za. 1138/ 18 Temmuz 1726).
}

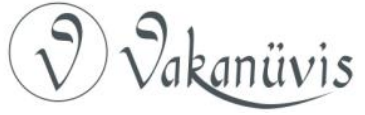


verildiği ifade ediliyordu. Gerekli unun ise Trabzon miri ambarından verilmesi emrolundu ${ }^{51}$.

Daha sonraki yıllarda da özellikle Anadolu'dan bölgeye iaşe malzemesi sevkiyatı devam etmiştir. 1730 yılında Erzurum mîri ambarından Sohum'a gönderilmek üzere 2.000 kile un nakli için mübaşir görevlendirildi. Unun Erzurum'dan Trabzon'a nakli, buradan da gemilerle Sohum Kalesi'ne gönderilmesi emredildi ${ }^{52}$.

Kafkasların sahil şeridinde yapılan tahkimat ağılıklı olarak eşkıya saldırıları ve bölgeyle yapılan ticaretin güvenliğini sağlama maksadı gütmekte idi. Bu defa bölgede yaşayan Abazalar sahil şeridinde bulunan Osmanlı saldırmakta, tahribata yol açmakta idi. Yine bölge kalelerinden biri olan Anagra Kalesine saldırmış büyük hasar vermişlerdi. Kalenin tekrar tamiri için Faş muhafızı Elhac Halil Paşa görevlendirildi ${ }^{53}$.

\section{Asker İstihdamı}

Bölgede inşa olunan kalelerle birlikte askeri yapılanmasının da sağlanması gerekmekte idi. Bu maksatla özellikle İstanbul'dan çeşitli yeniçeri cemaatlerinden, muhtelif sayılarda asker Sohum Kalesi'nde istihdam olundu. Aşağıdaki tablolarda konuyla ilgili ayrıntılı bilgi bulunmaktadır.

\section{6-1729 yılları arasında kalede görev yapan askerler ${ }^{54}$}

\section{Tablo 1}

\begin{tabular}{|l|l|l|l|r|}
\hline Bölük ismi & Sene & Asker & Gün & Ekmek/çift \\
\hline $\begin{array}{l}\text { Altıncı cemaat 7. Sekban } \\
\text { bölüğü }\end{array}$ & 1138 & 154 & 708 & 109032 \\
\hline $\begin{array}{l}\text { Altıncı cemaat yedinci bölük } \\
\text { sekbanı }\end{array}$ & 1140 & 166 & 354 & 58764 \\
\hline
\end{tabular}

${ }^{51}$ BOA, C.AS, 726/30438 (18 Za. 1138/ 18 Temmuz 1726).

${ }^{52}$ BOA, MAD. d, 521, s. 74 (17 B. 1143/ 26 Ocak 1731).

${ }^{53}$ BOA, C.AS, 1181/52669 (4. Ş. 1146/ 10 Ocak 1734).

${ }^{54}$ BOA, MAD. d, 2455, s. 13. Defterin ilgili sayfasında kale muhafazasında görev alan askerlere günlük verilen ekmek sayısını belirtmek maksadıyla hesaplamalar yapılmıştır. Biz bu hesaplamalardan aşağı-yukarı kalede yıllık kaç askerin görev yaptığı bilgisine de ulaşabilmekteyiz. Diğer tablolarda aynı bilgiyi göstermeyi lüzumlu görmedik.

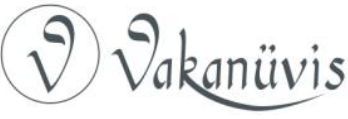




\begin{tabular}{|l|l|l|l|r|}
\hline $\begin{array}{l}\text { Altıncı cemaat yedinci bölük } \\
\text { sekbanı }\end{array}$ & 1141 & 166 & 354 & 58764 \\
\hline $\begin{array}{l}\text { Altıncı cemaat yedinci bölük } \\
\text { sekbanı }\end{array}$ & 1142 & 170 & 354 & 60180 \\
\hline 99. cemaat & 1143 & 169 & 354 & 24426 \\
\hline Toplam & & 725 & 2124 & 311166 \\
\hline $\begin{array}{l}\text { Meblağı } \\
\text { para }\end{array}$ \\
\hline
\end{tabular}

Tablo 2

\begin{tabular}{|l|l|l|l|l|l|}
\hline Bölük ismi & $\mathbf{1 1 3 8}$ & $\mathbf{1 1 3 9}$ & $\mathbf{1 1 4 0}$ & $\mathbf{1 1 4 1}$ & $\mathbf{1 1 4 2}$ \\
\hline Altıncı cemaat 7. Bölük sekban & 154 & 166 & 154 & 170 & $169^{55}$ \\
\hline 39. cebeci bölüğü & 62 & 23 & 73 & 73 & 59 \\
\hline Topçu bölüğü & 88 & 88 & 52 & 88 & 88 \\
\hline $\begin{array}{l}\text { Yerli askerler (mustahfız, } \\
\text { gönüllüyan-ı yemin gönüllüyan-ı } \\
\text { yesar, azeban, yerli topçuyan) }\end{array}$ & 210 & 210 & 210 & 210 & 210 \\
\hline $\begin{array}{l}\text { Yerli diğer askerler (beşliyan-ı } \\
\text { evvel, beşlüyan-ı sani, hendek } \\
\text { ocağı) }\end{array}$ & 80 & 80 & 80 & 80 & 80 \\
\hline Toplam & 594 & 567 & 569 & 621 & 606 \\
\hline
\end{tabular}

Tablo 3

\begin{tabular}{|l|l|l|l|l|l|}
\hline Bölük adı & $\mathbf{1 1 3 8}$ & $\mathbf{1 1 3 9}$ & $\mathbf{1 1 4 0}$ & $\mathbf{1 1 4 1}$ & $\begin{array}{l}\text { Gün } \\
\text { sayısı }\end{array}$ \\
\hline Toçu cemaati & 88 & 88 & 57 & 88 & 354 \\
\hline
\end{tabular}

1726-yılında kalede görev yapan askerlerin sayısına baktığımızda, bölgeden istihdam olunan yerli askerlerle birlikte 1442 askerin Sohum Kalesi muhafazasında bulunduğunu tespit etmekteyiz. 1729 yılına

${ }^{55}$ Sadece 99. Cemaat.

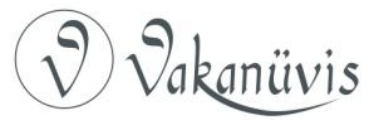


kadar takip eden yıllarda da aşağı yukarı aynı sayıda askerin muhafazada görevlendirildiğine şahit oluyoruz ${ }^{56}$.

Yukarıda yıllara göre asker sayısı olarak genel yekûna ulaşılmaya çalışılmıştır. Bununla beraber askerlerin değişik yıllarda kaleye gidişleri ve bu aşamadaki sürece de örnek vermek gerekir. Nitekim 1726 yılında Sohum Kalesi Bina Emini Mustafa'ya gönderilen emirde, kalede istihdam olunmak üzere ağa ve zabitan dâhil olmak üzere Beşliyan-ı evvel cemaatinden 20 asker; Beşliyan-ı sanî cemaatinden 20 asker; hendek ağalığı cemaatinden de 15 askerin istihdamından sonra, merkezden beratlarının tanzim edilmesi için bunların defterlerinin tutularak i̇stanbul'a gönderilmesi istendi ${ }^{57}$. Yine Sohum Kalesi muhafazasında yer almak üzere 210 asker gönderilmişs ${ }^{58}$ Sivas Mütesellimine gönderilen emirde, söz konusu askerlerin 1725 yılı için hak ettikleri bir yıllık mevacip tutarı olan 439,5 guruşu, kendilerine gönderilen mübaşir vasıtasıyla Sohum'a yollamaları istendi ${ }^{59}$.

Kafkasya'da yeniden inşa edilen kaleler silsilesi için Osmanlı coğrafyasının değişik bölgelerinden asker temini sağlandı. Nitekim Azak Muhafızı, defterdarı ve Kefe Nazırına gönderilen emirde, yeniden inşa olunan Faş, Sohum ve Soğucak kaleleri muhafazalarında yer almak üzere elli askerlik bir ortanın Azak Kalesi'nden gemilerle bölgeye gönderilmesi istendi. Askerlerin iaşesi için, Azak'ta bulunan mîrî peksimetten her bir askere yarımşar kantardan 25 kantar verilmesi de emredildi. Hotin muhafızına da benzer bir emir gönderilerek söz konusu kalelerin muhafazalarında yer almak üzere Hotin'den 50 topçu askerin Kili üzerinden bölgeye gönderilmesi istendi. Kili nazır ve kadısından da Kili İskelesinden gemilere bindirilecek askerilerin iaşesi için yine her bir askere yarımşar olmak üzere toplam 25 kantar peksimet verilmesi emredildi ${ }^{60}$.

Asker istihdamı ve yoklaması ile ilgili bir örnekte ise Bina Emini Mustafa'ya gönderilen emirde, kendinden önceki Bina Emini Yusuf Bey zamanında kale muhafazasında 168 askerin görevlendirildiği İstanbul'a

\footnotetext{
${ }^{56}$ BOA, MAD, d, 2455, s. 13.

${ }^{57}$ BOA, AE, SAMD. III, 204/19667 (8 Ş. 1139/ 31 Mart 1727).

${ }^{58}$ BOA, MAD, d, 9915, s. 332 (24 B. 1138/ 28 Mart 1726).

${ }^{59}$ BOA, MAD, d, 9915, s. 345 (6 Ş.1138/ 9 Nisan 1726).

${ }^{60}$ BOA, IE, AS, 67/6083 (25 Za. 1136/ 15 Ağustos 1724).
}

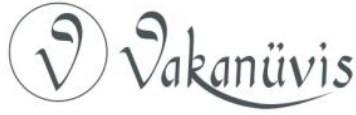


tahrir edildiği ifade edilmiş, Yusuf'un vefat etmesi üzerine kendisinden tekrar asker yoklaması yaparak defteri İstanbul'a göndermesi istendi ${ }^{61}$.

\section{Kale için Mühimmat Temini}

Asker istihdamı ile birlikte kalenin mühimmat ve cephane bakımından da takviye edilmesi gerekmekte idi. Bu maksatla çeşitli yıllarda kaleye askeri malzeme takviyesi yapıldı. 17 Mart 1725 yılında Sohum Kalesine Cebehane-i âmireden başta 50 kantar siyah barut, , 50 kıyye Kara Demir fitili, 10 kantar zift, 10 kantar katran ve 50 kılıç olmak üzere çeşitli türden inşaat malzemeleri gönderildi ${ }^{62}$. 19 Şubat 1729 tarihinde de kaleye 50 kantar siyah barut, 50 kantar kurşun, 50 kantar fitil-i mısrî ve çeşitli türden inşaat malzemeleri gönderildi. Aynı yıl içerisinde Tophane-i âmireden beş adet üç vukıyyelik; beş adet de 1,5 vukıyyelik olmak üzere toplam 10 adet top gönderildi ${ }^{63}$.

Tophane ve Cebehaneden, dört tane 3 vukıyyelik ve 10 karış; dört tane 1,5 vukıyyelik ve yedi karış olmak üzere toplam sekiz adet demir topla birlikte kundak, tekerlek gibi muhtelif mühimmat ve bunların imali için 2.719 vukıyye ham demir Sohum kalesine gönderildi. 9 Nisan 1727 'de yine Sohum kalesine beş adet demir topla kundak, tekerlek gibi mühimmat gönderildi. 9 Eylül 1729 tarihinde de üçü üç karışlık dördü ise 1,5 karışlık olmak üzere toplam yedi adet top, kundak tekerlek vs. mühimmat gönderildi ${ }^{64}$. Bunların dışında 26 Ocak 1731 tarihinde 100 kantar siyah barut, 30 kantar kurşun, 330 Tatar yayı, 50 kılıç, 50 tüfek, 30 balta, 30 demir kazma, çeşitli türde çuvallar vs. mühimmat Sohum Trabzon cephanesi mevcudundan gönderilmesi emredildi. Gönderilecekler arasında toplar için mühimmatıyla birlikte 30 top kundağı ve 60 tekerleği de bulunmakta idi ${ }^{65}$.

Sohum Kalesine 5 Haziran 1732'de başta 100 kantar barut, 30 kantar kurşun olmak üzere çeşitli türden mühimmat gönderildi ${ }^{66}$. Faş, Sohum, Gönye ve Batum'a saldırarak hasar veren Abaza eşkıyası ile mücadele etmek üzere Faş Muhafızı Elhac Halil Paşa görevlendirilmişti.

\footnotetext{
${ }^{61}$ BOA, MAD, d, 9915, s. 132 (18 Ra. 1138/ 24 Kasım 1725).

62 BOA, MAD. d, 16010, 1,2 (21 B. 1137/ 5 Nisan 1725).

${ }^{63}$ BOA, MAD. d, 16010, 3, 7 (20 B. 1141/ 19 Şubat 1729).

${ }^{64}$ BOA, MAD. d, 521, s. 72 (23 B. 1137/ 7 Nisan 1725).

${ }^{65}$ BOA, MAD. d, 521, s. 74,-76 (23 B. 1143/ 7 Nisan 1725).

${ }^{66}$ BOA, D.BŞM.CBH. d, 18387, s. 9 (11 Z. 1144/ 5 Haziran 1732).
}

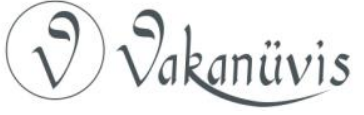


Paşanın maiyyetinde yer alan askerlerin tayinatı için 3 Ekim 1731'den 13 Haziran 1733'e kadar ödeme yapılmıştı. Bir yandan Abaza kabilesinden eşkıyalık yapanlarla mücadele edilirken diğer yandan söz konusu kabilenin ileri gelen beylerinin gönlünü hoş tutmak için onlara da gerek hediye gerek mühimmat gerekse zahire olarak yardımda bulunulmakta idi. Nitekim Elhac Halil Paşa, Abaza beyleri için 4.248 Kuruş değerinde çeşitli türden zahire temin etmişti ${ }^{67}$.

\section{Sonuç}

1730 yılına kadar tamamlanan Faş Soğucak ve Sohum kaleleri Rus tehdidinin arttığı yüzyılın ikinci yarısına daha çok bölgede asayişin temininde aktif rol oynadığını görürüz. İnşa edildikleri tarihten itibaren değişik zamanlarda yine kapsamlı tamirat evreleri geçiren kalelerin, özellikle 1768-1774 ve 1787-1792 savaşları öncesinde ve sonrasında üstlendikleri görev daha da ağırlaşmıştır. Zira kaleler daha önceleri eşkıyalık faaliyetlerine engel olunmak maksadıyla tahkim edilirken bu tarihlerden itibaren Rus tehdidine karşı tahkim edilmişler Osmanlı'nın Karadeniz sularının bu bağlamda Anadolu'nun güvenliği için hayati rol oynamaya başlamışlardır. Söz konusu savaşlarda birkaç kez el değiştiren kaleler her defasında yeniden ve eskisinden daha güçlü olarak tahkim edilmişlerdir. 1785 yılında Kuzey Kafkasya'da inşa edilen ve kısa zamanda Osmanlı Devleti'nin lojistik ve askeri üssü halini alan Anapa Kalesii ${ }^{68}$ ile birlikte Soğucak, Faş ve Sohum kaleler zinciri, Karadeniz' de Rus tehdidine karşı savunma bloğu oluşturmuştur.

Her biri ayrı bir çalışma sahası olan kalelerden incelemeye çalıştı̆̆ımız Sohum Kalesi 1806-1812 Osmanlı Rus savaşlarında diğer kaleler Faş, Anagra ve Kemhal kaleleri ile birlikte Ruslar tarafından işgal edilmişti. İki ülke arasında 16 Mayıs 1812 tarihinde akdolunan Bükreş Antlaşması ile diğer yukarıda bahsi geçen kalelerle birlikte Sohum'un da Osmanlı Devleti'ne iade edilmesi karar antlaşma hükümleri arasında yer almıştı ${ }^{69}$. Antlaşma öncesi söz konusu 1806-1812 Osmanlı Rus

\footnotetext{
${ }^{67}$ BOA, MAD. d, 6758, s. 7-8 (3 M. 1144/ 8 Temmuz 1731).

${ }^{68}$ Ayrıntılı bilgi için bkz. Cengiz Fedakar, Kafkasya'da İmparatorluklar Savaşı, (İş Bankası Kültür Yayınları), İstanbul 2014.

69 Muahedat Mecmuası, C. IV, s.52; Cemal Gökçe, Kafkasya ve Osmanlı Imparatorluğu'nun Kafkasya Siyaseti, İstanbul 1979, 206-207; Bu anlaşma ile Ruslar
}

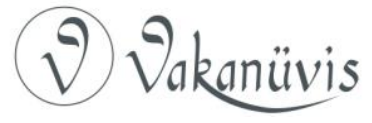


savaşlarında çalışma konumuz olan Sohum Kalesi 9 Temmuz 1810'da Rus işgaline maruz kalmıştı. Sohum, Osmanlı hakimiyetinde iken 1775 yılında Müslümanlığı kabul eden Cacba/Şervaşidze Hanedanına mensup Abhaz Beyi Sefer Bey idaresinde idi. Sefer Bey sonradan Hıristiyanlığı kabul ederek Rus idaresine geçtiğini ilan etmiş, çocuklarını da eğitim için Rusya'ya göndermişti ${ }^{70}$.

1812 'de Faş kalesi, 1813 yılında yapılan müzakereler neticesinde ise işgal altında olan Anapa ve Soğucak kaleleri Osmanlı Devleti'ne iade edilmişti. Fakat Anagra, Kemhal ve Sohum kaleleri iade edilmemişti. Trabzon Valisi Hazinedarzade Süleyman Paşa tekrar askeri harekâtla Sohum'u ele geçirmeye çalışmış lakin muvaffak olamamıştı ${ }^{71}$.

Cemal Gökçe, eserinde 1814 yılında Sohum Beyi Keleş (Gülşen) Ahmed Bey'in oğlu Sefer Bey'in kaleyi Ruslara teslim ettiğine dair şayialar olduğunu, Sefer Bey'in babalığı (kayınpederi) Ahmet Ağa, Sefer'in suçunun affı mukabilinde kalenin tekrar Osmanlı'ya teslim edileceğini yazması üzerine, İstanbul'dan bu doğrultuda ferman gönderilmesi ile Sohum'un yeniden Osmanlı Devleti'ne teslim edildiğini ifade etmiştir ${ }^{72}$. Fakat faydalandığı Osmanlı Arşiv vesikalarında ${ }^{73}$ Ruslarla bu hususta müzakereler yapıldığı, kaleyi Ruslardan devralmak üzere görevliler atandığı yazmakla birlikte, Sohum'un Osmanlı idaresine devredildiğine dair bilgi bulunmamaktadır. Başka bir kaynakta ise Ekim 1821'de Sefer Bey'in ağabeyi Aslan Bey Çaçba liderliğinde Abhaz halkının Rus idaresine karşı ayaklandığı, bölge ahalisinin de desteği ile Abhazya'nın tamamına sahip olduğu, hatta Sohum Kalesi'ni bile zapt ettiği yazmaktadır. Aynı müellif 1824 yılında Yine Arslan Bey tarafından Rus idaresine karşı ayaklanma olduğu fakat bu defa Rus generali Gorchakov'un bu ayaklanmayı "vahşice" bastırdığı ifade edilmektedir ${ }^{74}$. Müellif 7 Ekim 1826 tarihinde Osmanlı Devleti ile Rusya arasında yapılan Akkerman Antlaşması ile Osmanlı́nın,

işgal ettikleri Osmanlı topraklarından sadece Basarabya'yı muhafaza ettiler Enver Ziya Karal, Osmanlı Tarihi, C. V, s. 100.

${ }^{70}$ Bilge, Osmanlı Çağı'nda..., 351.

${ }^{71}$ Bilge, Osmanlı Çağı'nda..., 354.

${ }^{72}$ Gökçe, 210,211.

${ }^{73}$ BOA, HAT, 44567 a; 44596.

${ }^{74}$ Açugba, 45.

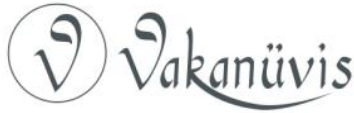


Abhazya'nın Rusya'ya katılımını tanıdığını yazmaktadır ${ }^{75}$. Fakat söz konusu antlaşmanın birinci maddesinde her iki ülkenin Bükreş antlaşması maddelerinin kabulünü teyit ettiği şeklindedir ${ }^{76}$. Dolayısıyla Sohum'un Osmanlı Devleti'ne iadesinin teyididir. Konuyla ilgili Akkerman Antlaşmasının dördüncü maddesinde, 1812 Bükreş Antlaşması gereğince Anadolu sınırlarında Rusların işgal ettiği kale ve beldelerden çekilmesi, her iki ülkenin sınırları dâhilinde kalan halkının asayişlerinin temin edilmesi yükümlülüğü taahhüt altına alınır ${ }^{77}$. Konuyu Rus kaynaklarında da tetkik ettiğimizde, bir fark olmayıp, orada da 1812 Bükreş Antlaşması'nın altıncı maddesi gereğince sınırların savaş öncesi duruma getirilmesi, diğer bir ifadeyle Rusların işgal ettikleri kale ve beldelerden çekilmesi yine teyit edilmektedir. Türkçe antlaşma metninden farklı olarak Rusçasında, Osmanlı Devleti'nin bu kalelerde sadece savaş zamanında asker bulunduracağını taahhüt ettiği belirtilmektedir ${ }^{78}$. Bununla birlikte Sohum'un Bükreş Antlaşması'ndan itibaren, resmiyette antlaşmalarla Osmanlı idaresinde olduğu teyit edilmiş olsa da, yukarıda da bahsi geçtiği üzere şehrin yerel beylerinin gerek kendi idaresini temine çalışması gerekse kaleyi Ruslara teslimi ile birlikte, fiili olarak bölgede Rus idaresi hâkim idi. Zaten birkaç yıl sonra çıkan 1828-1829 OsmanlıRus savaşları, Osmanlı Devleti'nin ağır hezimetiyle sonuçlanmış, 1829 Edirne Antlaşması'nın dördüncü maddesi gereğince Kafkasların tamamı Rusya'ya bırakılmıştır ${ }^{79}$. Sohum 1877-1878 Osmanlı Rus harplerinde kısa süreliğine tekrar Türk idaresine geçmişti. Bu zaman zarfında Osmanlı Sultanı II. Abdülhamid tarafından Sohum Kalesi'nin kitabesi İstanbul'a getirtilmiş ve Topkapı Sarayı Bahçesine yerleştirilmiştir (ek: 2). 1914 yılında Türk donanması şehri bombardımana tutmuştu ${ }^{80}$.

Incelemeye çalıştığımız Sohum Kalesi/şehri Abhazya çalışmamızın başlarında da belirttiğimiz üzere Abhazya Cumhuriyeti'nin başkenti Sohum'dur.

\footnotetext{
${ }^{75}$ Açugba, 47.

${ }^{76}$ Muahedat Mecmuası, C. IV, 58.

${ }^{77}$ Aynı eser, 60.

${ }^{78}$ Yuzefoviç, T., Dogovorıy Rossii s vostokom politiçeskie i torgovye, Petersburg 1869, s. 60-61.

${ }^{79}$ Gökçe, 245; Karal, 121.

${ }^{80}$ İnisimof, 103.
}

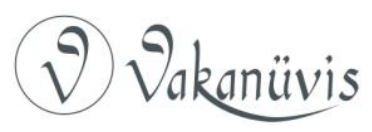




\section{KAYNAKÇA}

\section{Başbakanlık Osmanlı Arşiv Vesikaları}

AE, SAMD. III, 204/19667, AE, SAMD.III, 109/10722, AE.SMHD.I, 233/18711, C.AS, 1181/52669, C.AS, 585/24639, C.AS, 585/24639, C.AS, 650/27323, C.AS, 726/30438, C.AS, 726/30438, C.AS, 726/30438, C.BH, 9/440, C.BH, 9/440, , D.AMH.d 24788, D.BKL. d, 32442, D.BKL.d, 32442, D.BŞM, BNE, d, 15889, D.BŞM.BNE, 1/60, D.BŞM.BNE, 2/90., D.BŞM.BNE, 3/13, D.BŞM.BNE, 3/18, D.BŞM.BNE, 3/19, D.BŞM.BNE, 3/20 D.BŞM.BNE, 3/21, D.BŞM.BNE, 3/28, D.BŞM.BNE, 3/36, D.BŞM.BNE, 3/37, D.BŞM.BNE,2/78 D.BŞM.CBH. d, 18387, HAT, 44567 a, HAT, 44596, iE, AS, 67/6083, IE, ML, 121/11475, MAD, 521, MAD, d, 9915, MAD. d, 1471, MAD. d, 16010, MAD. d, 2455, MAD. d, 6758.

\section{Literatür}

Şimşirgil, Ahmet, Taşa Yazılan Tarih Topkapı Sarayı, Tarih Düşünce Kitapları, İstanbul 2005.

Arşiv Belgelerine Göre Osmanlı Kaleleri, T.C Başbakanlık Devlet Arşivleri Genel Müdürlüğü, Osmanlı Arşivi Daire Başkanlığı, Yayın No: 144, İstanbul 2016.

Gökçe, Cemal, Kafkasya ve Osmanlı Imparatorluğu'nun Kafkasya Siyaseti, İstanbul 1979.

Fedakar, Cengiz, Kafkasya'da İmparatorluklar Savaşı, (İş Bankası Kültür Yayınları), İstanbul 2014.

Karal, Enver Ziya, Osmanlı Tarihi, C. V.

Uzunçarşıı, İsmail Hakkı, Osmanlı Tarihi, C.III, Kısım I.

Bilge, M. Sadık, Osmanlı Devleti ve Kafkasya, İstanbul 2005.

Bilge, M. Sadık, Osmanlı Çağı'nda Kafkasya, 1454-1829 (TarihToplum-Ekonomi), İstanbul 2015.

Aydın, Mahir, " Faş Kalesi", Osmanlı Araştırmaları VI, İstanbul 1986.

Aydın, Mahir, "Kaf Dağı'nda Türk Kalesi", Türklük Araştırmaları Dergisi, S. 20.

Bala, Mirza, "Gürcistan" mad, MEB, Islam Ansiklopedisi, C. 4, İstanbul 1978.

Muahedat Mecmuası, C. IV.

Aydın, Mustafa, Üç Büyük Gücün Çatışma Alanı Kafkaslar, İstanbul 2005.

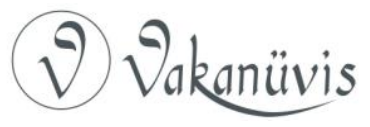


İnsimof, Sergey, Kafkas Kılavuzu (Çev. Binbaşı Sadık), İstanbul 1926. Açugba, Timur, Kronolojik Abhazya Tarihi, (çev., Oktay Chkotug) İstanbul 2015.

Yuzefoviç, T., Dogovorly Rossii s vostokom politiçeskie i torgovye, Petersburg 1869. 
EK 1: Sohum Kalesi Keşif defteri ${ }^{81}$

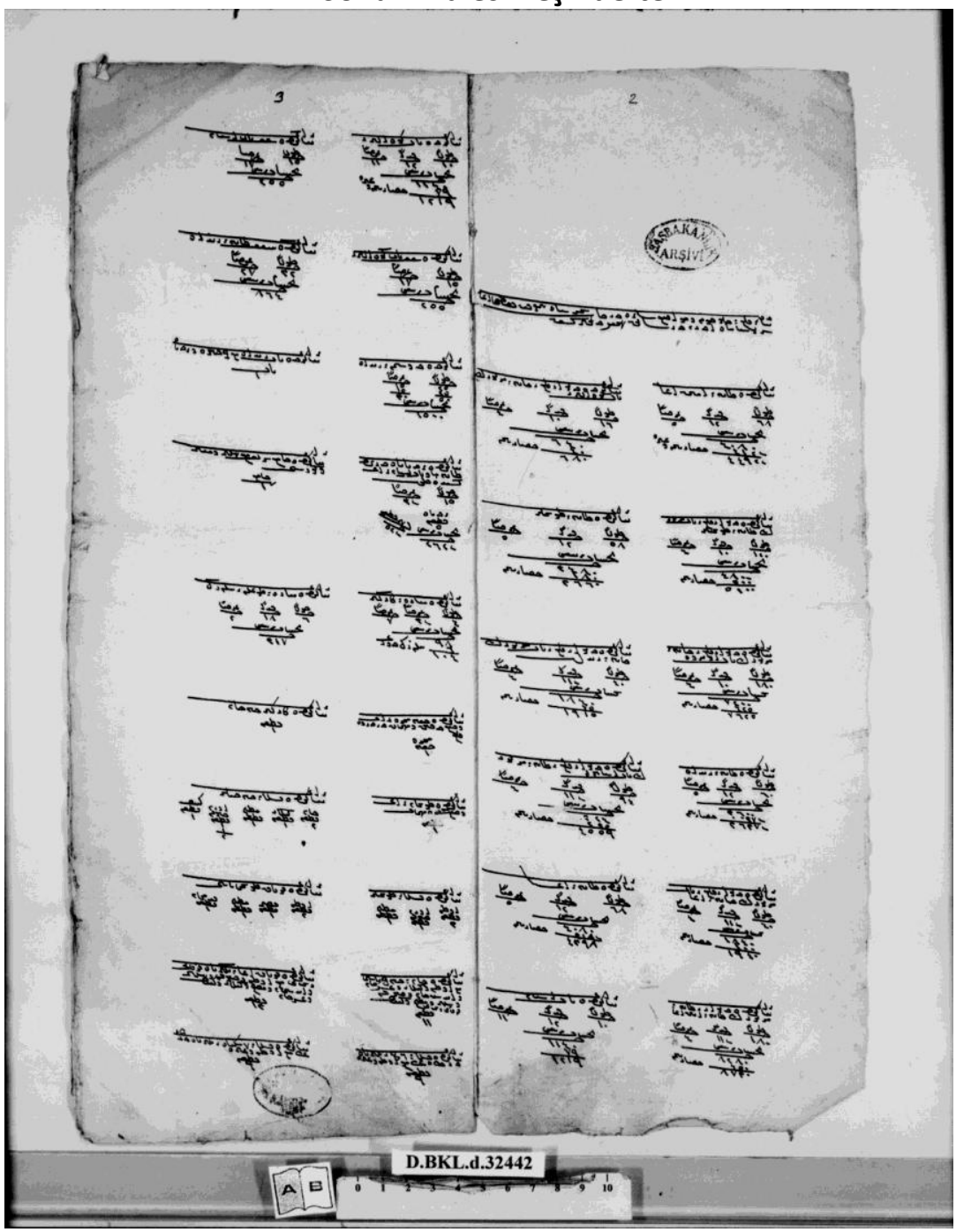

${ }^{81}$ BOA, D.BKL.d, 32442. 
EK 2: İstanbul Topkapı Saray Bahçesinde bulunan Sohum Kalesi Kitabesi

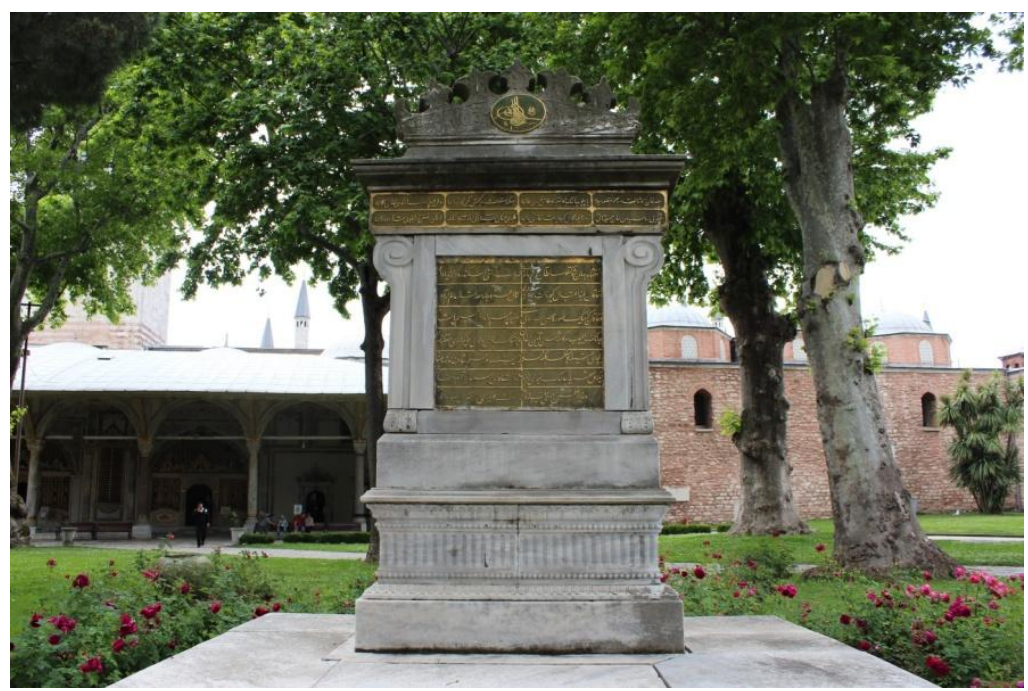

Abidenin üzerinde Sultan II. Abdülhamid'in 1294/1877 tarihli tuğrası bulunmaktadır.

Kitabesinde ise şu ifadeler yer almaktadır:

Asr-ı Han-ı Ahmed-i sâliste Sohum kal'ası da

Yapılıp bâbının üstüne bu taş kondı heman

Sonra Moskof eline geçmiş iken nice zaman

Vatan-ı yevm olub oldu nizamı talan

Kaleyi Rusiye'den Han-ı Hamîd-i sânî

Zor ile aldı gerüye şeh-i gâzi-yi zaman

Geldi zaman-ı Hümâyunu ile işte bu senk

Buraya vaz'ını emreyledi şâh-ı devrân

Şehinşâh-ı cihân şevketlü Sultan Ahmed Gâzi

Ki bâb-ı devlet-i İskender-ü Dârâ'ya me'vâdır

O hakan-ı bülend-ikbâl kim zât-ı hümâyunu

Kemâl-i izz ü câh-ı madeletle âlem-ârâdır

O hakan-ı güzînin sıhr-ı hâs-ı sadr-ı âlisi

Vezir-i pür-himem Damad İbrahim Paşa'dır

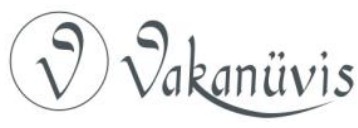


Cihanın eyleyüb her kûşesini temin a'dadan Bu semtin dahi oldı çünki emri hıfıına sâdır Yapıldı himmetiyle bu muazzam kal'a-i muhkem Ki heybetle sanursın-kim ser-i Kaf üzre 'ankadır Kıla Hakk şehriyâr-ı âlemin ikbâlini efzûn Ki zât-ı akdesi sermâye-i ârâm-ı dünyadır Vezir-i azamı dahi kıla dâim Ki bâis böyle emn ü rahata ol sâdr-ı dânâdır ${ }^{82}$

\section{EK 3: Sohum Kalesi Planı $(1854)^{83}$}

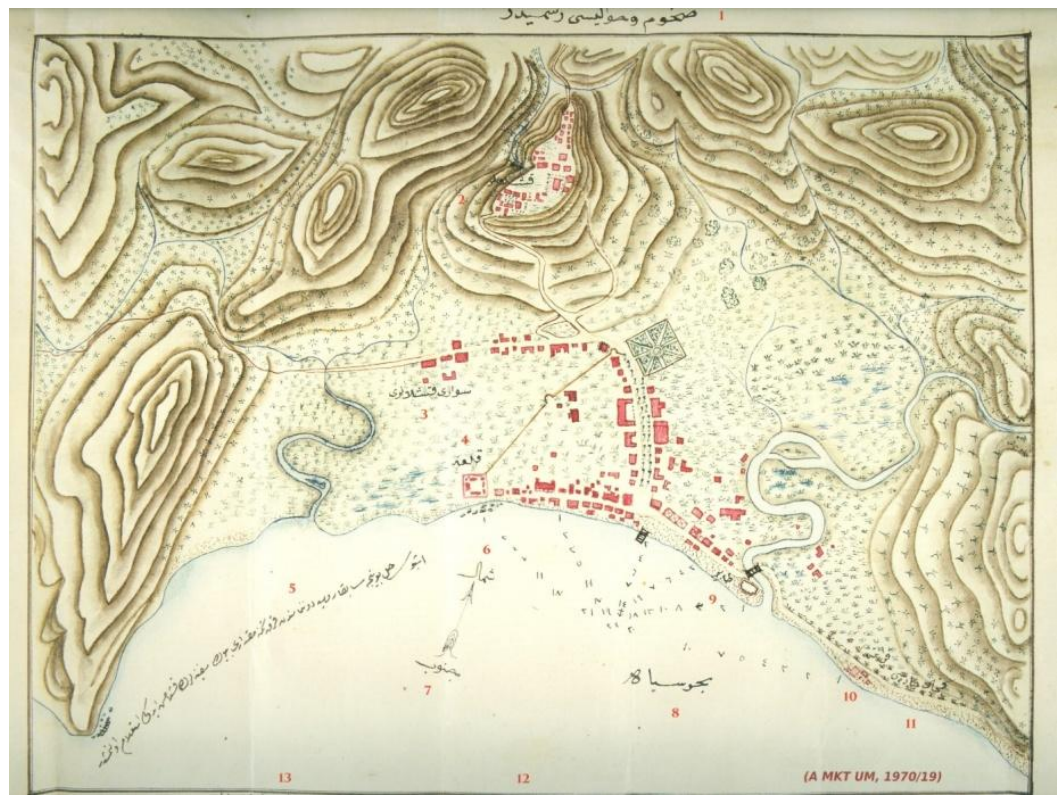

82 Ahmet Şimşirgil'den naklen, Taşa Yazılan Tarih Topkapı Sarayı, Tarih Düşünce Kitapları, İstanbul 2005, 83.

${ }^{83}$ Arşiv Belgelerine Göre Osmanlı Kaleleri, T.C Başbakanlık Devlet Arşivleri Genel Müdürlüğü, Osmanlı Arşivi Daire Başkanlığı, Yayın No: 144, İstanbul 2016, s. 211. 